\title{
IS EFFECTIVE ENFORCEMENT OF THE FIDUCLARY DUTIES OF CORPORATE MANAGERS PRACTICABLE?
}

\author{
E. MERRICK DODD, JR.*
}

$I^{1}$ T HAS become a commonplace observation that capitalism, an economic system with which western Europe and North America have been familiar since the Industrial Revolution, has recently passed, particularly in this country, into a new phase-the phase of the largescale corporation. Capitalism of this type presents two vitally important problems for the student of our legal and economic institutions. The first and major problem is whether such capitalism is or can be made safe for the community, particularly for those large sections of the community which are composed of persons who are not primarily capitalists but laborers and consumers. Assuming, as most Americans do, that an affirmative answer can be made to this question, the second question which arises is whether this form of capitalism is or can be made safe for that section of the community which it is intended most directly to benefit 一the capitalist investor.

Effective legal regulation of the conduct of any group in the community is difficult of attainment unless the regulations imposed are reasonably in accord with the normal desires of the more influential members of the group regulated. This is especially true where the group to be regulated is powerful or has powerful allies among other sections of the community and where the group for whose benefit the regulation is imposed is unorganized and weak. If with this in mind we turn to the legal principles which governed capitalism in the pre-corporate stage of its development, we find that the conditions which then existed were such as to make such regulation of the capitalist as was then thought to be desirable reasonably assured of success. The fundamental legal principle applicable to business enterprises in the early nineteenth century régime of free competition was that of giving the widest possible scope to the acquisitiveness of the owners of business. Their activity and efficiency were stimulated both by the freedom granted to them of seeking unlimited profits and by the fostering of competition which made the securing of profit difficult except for the

* Professor of Law, Harvard University Law School. 
active and the able. Moreover, such legal limitations upon acquisitiveness as did exist, ${ }^{x}$ restraints upon monopoly and legal rules imposing penalties for the use of force or fraud as devices for increasing profits, being in the interest not only of the community at large but-in their application to their rivals - of the competing capitalists themselves, had a reasonable chance of successful enforcement. ${ }^{2}$

It is true that long before the transformation of the capitalist system through the development of the corporation, much of the business activity of the community was carried on not by the owners of business enterprises but by their agents and employees. Obviously, as soon as we introduce an employee into our picture, our principle of legally approved acquisitiveness as the mainspring of business activity requires substantial modification. In bargaining with his principal with respect to wages and other conditions of employment an employee may, with the law's benediction, be as acquisitive as he likes. Once the bargain it struck, however, new principles enter. In addition to the general legal duty of conformity of conduct to the terms of the bargain made, a duty imposed upon all contracting parties, the law imposes upon the employee the special legal duty of loyalty owed by one who stands in a fiduciary relation to some other person. This duty of loyalty, as applied to business activities engaged in by one in the position of employee, is the duty of so disciplining one's acquisitive impulses that they will operate vicariously so as to increase to the maximum extent possible not one's own acquisitions but those of one's employer. Since the latter may be, and often is, a person with whom the employee is not united by any bond of kinship or friendship, this attempted transformation of acquisitiveness from a purely self-regarding motive to one of a radically different sort undoubtedly encounters serious psychological difficulties. Nevertheless, so long as most business enterprises are small and are personally supervised by their owners, the difficulties in giving effective enforcement to this legal principle of vicarious acquisitiveness are not dismayingly serious. For so long as the employee carries on most of his activities either directly under the eye of his employer or

It is immaterial for our purposes whether acquisitiveness is an instinct or an acquired characteristic. It is in any case a sufficiently dominant motive in the behavior of the modern man of business so that a legal order which gave it substantially free rein was satisfactory to him.

2 Until the advent of the large corporation and of mass production by machine methods, the legal prohibition of monopoly was reasonably effective. Despite such incidents as those described in C. F. and H. Adams, Chapters of Erie and Other Essays (I886), the use of force in business, except in labor disputes, seems to have been unusual in the nineteenth century United States. Fraud was less effectively dealt with, but considerable progress was made in eliminating its cruder forms from reputable business. 
subject to the latter's careful inspection as to results, the rewards of loyalty and the penalties of loss of the job and inability to obtain employment from others which are likely to result from disloyalty are of so substantial a character that the employer's need to resort to the courts in order to secure from his employee conduct which measures up to the legal standard is likely to be infrequent. Moreover, in cases in which such resort proves to be necessary, the facts will generally be sufficiently known to the employer so that he can prove his case and thereby induce the legal tribunal to deal with disloyalty in appropriate fashion.

If for the individual employer and employee we substitute the small corporation with its stockholders and directors, the situation is not radically changed. No doubt, even where the corporation is small, the control exercised by its stockholders over its directors is markedly less effective than that of the individual owner of a small business over his employees. During the first half of the nineteenth century-the period during which the relatively small corporation was largely taking the place of the individual entrepreneur - this weakening of owner-control seems to have been largely compensated for by the fact that directors usually held relatively large blocks of stock themselves or were intimately connected by family or other ties with large stockholders, so that the self-interest of the directors was to a very large degree identical with the self-interest of the stockholder-owners. ${ }^{3}$

Of recent years this state of affairs-so comforting for the corporate investor-has radically changed. We all know, or if we do not we may find the evidence effectively marshalled for us by Berle and Means, ${ }^{4}$ that a very large and apparently increasing portion of the business of the country is carried on by large corporations so organized that ownership and control are predominantly in separate hands. The directors of these gigantic enterprises and their intimate associates frequently own only a very small proportion of their securities, ${ }^{5}$ and those who do own them are in fact and sometimes-owing to such devices as nonvoting stock-even in legal theory incapable of exercising any effective voting control over the directors.

3 This seems to have been the usual situation, although some relatively large corporations were formed during the first half of the nineteenth century, including the leading banks and insurance companies, the railroads, and the Lowell, Massachusetts, cotton mills, and stock ownership in some of these was quite widely diffused. See Ware, The Early New England Cotton Manufacture (I93r), I49-15r.

4 Berle and Means, The Modern Corporation and Private Property (r932).

s See Berle and Means, sucpra note 4 . 
As a result of the limited stake which the directors have in these enterprises and of the division of their security holders ${ }^{6}$ into classes with diverse and partially conflicting interests, it is often far more profitable for the directors and managers of these enterprises to seek gains at the expense of the security holders or some class of security holders, rather than to seek loyally to obtain the maximum amount of profits for them-provided, of course, that the risk that such conduct will be detected and punished is relatively slight. Unfortunately, several factors have united to make the risk of detection and effective punishment much less than anyone upholding the investor's interests would desire. Punishment through being voted out of office is, as indicated above, today a relatively unlikely event. ${ }^{7}$ Criminal prosecution is comparatively rare, ${ }^{8}$ and civil liability is-so long as the management remains in office-possible only by means of the stockholder's suit. The difficulties which beset the stockholder in attempting to obtain the information necessary to prove a case of disloyalty in such a suit, ${ }^{9}$ the ease with which an ingenious management may give a color of business necessity to many kinds of disloyal conduct, the cost of such litigation, the fact that stockholders are not properly organized for collective court action, ${ }^{\text {To }}$ the indirect nature of the benefit to the stockholder which results from its successful prosecution, ${ }^{\text {II }}$ the limitations which the courts have placed upon the class of persons eligible as

\footnotetext{
${ }^{6}$ The word "security-holders" has been used instead of "stockholders" because the bondholders no less than stockholders may suffer as a result of managerial wrongdoing. In legal theory, however, the managers are fiduciaries only for the corporation and thus are in no sense fiduciaries for the bondholders who are not members of the corporation.

7 The difficulties in bringing about concerted action by scattered stockholders to oust a dishonest management are primarily due to their inertia, their ignorance of the facts, and the usual lack of an anti-management leader whom they know and trust. The purchase of a large block of stock by some outside interest may bring about a change in the management, but there is little comfort for the small investor in this fact.

8 Except in times of strong public feeling, when managers may sometimes be convicted even on charges of rather technical wrongdoing. Cf. People v. Marcus, 26r N.Y. 268, r85 N.E. 97 (1933).

- Despite the stockholder's legal right to examine the books, the discovery by him of cleverly concealed wrongdoing in connection with highly complicated transactions is both expensive and difficult. Moreover, the right of a stockholder in a parent corporation to examine the books of a subsidiary is far from clear. State v. Sherman Oil Co., 3I Del. 570, II7 Atl. r22 (I922). But cf. Martin v. The D. B. Martin Co., Ic Del. Ch. 2rI, 88 Atl. 6r2 (Igr3); Woodworth v. Old Second National Bank, I54 Mich. 459, Ix7 N.W. 893 (Igo8).

so Perhaps the formation of stockholders' protective associations, such as the Shareholders Protection Association, Itd., recently organized in England, may do something to remedy this difficulty.
}

"Money or property recovered does not belong to him but to the corporation. 
plaintiffs, ${ }^{12}$ and the uncertainty which exists as to whether certain kinds of conduct which to the man in the street seem palpably disloyal are legally actionable, ${ }^{{ }^{3} 3}$ tend to deprive this type of suit of much of its effectiveness as a deterrent.

It may well be that it would be possible, if judges, legislators, and administrative officials, and those who are in a position to influence their conduct $^{x_{4}}$ should devote sufficient attention to the matter, to strengthen at important points the legal safeguards which protect the investor from managerial disloyalty. If present rules of substantive law stand in the way, these may be changed; and, in so far as the difficulty is rather with the enforcement of existing rules than with their content, more effective devices for making law in action conform to law in books may conceivably be found. ${ }^{\mathrm{Is}}$ Nevertheless, as indicated at the beginning of this article, en-forcement of legal rules governing the conduct of a powerful group tends to be ineffective unless the content of these rules finds approval in the

12 The rule which prevails in the federal and some of the state courts that only persons who held stock at the time of the wrongdoing can bring suit may have the effect, in the case of a corporation whose stock has an active market, of cutting down the list of eligible plaintiffs to zero if considerable time elapses before the wrong is discovered.

${ }^{23}$ Thus it has recently required an appeal to the Supreme Court of the United States to establish the proposition that it might be a legal wrong for corporate officers, relying on a bylaw enacted by the stockholders twenty years before when conditions were radically different, to pay themselves bonuses which in the case of the president amounted to over $\$ 800,000$ a year. Rogers v. Hill, 289 U.S. 582 (I933). It is still law in many states that a director may, in purchasing shares from a stockholder, take advantage of inside information acquired by virtue of his position. Goodwin v. Agassiz, I86 N.E. 659 (Mass. x933); Keely v. Black, 9r N.J. Eq. 520, III Atl. 22 (I920); Cahall v. Lofland, I2 Del. Ch. 299, II4 Atl. 224, I3 Del. Ch. 370, Ir8 Atl. I (I922).

Where a contract is made by interlocking directors, some courts, impressed with the desire not to interfere unduly with the security of transactions, have held that one attacking the transaction must sustain the burden of proving unfairness. Wentz v. Scott, 10 F. (2d) 426 (C.C.A. 6th I926); Crowell \& Thurlow S.S. Co. v. Crowell, 280 Mass. 343 , 182 N.E. 569 (I932). This rule has even been applied to transactions in which directors have a direct personal interest adverse to that of their corporations. Meyer v. Fort Hill Engraving Co., 249 Mass. 302 , I43 N.E. $9{ }^{5}$ (r924). Since the plaintiff in such cases is usually a minority stockholder with an imperfect knowledge of the facts, the danger to stockholders created by such holdings is obvious.

${ }^{14}$ Since legislatures are influenced chiefly by well organized groups, the lack of effective organization on the part of investors means that their grievances are likely to arouse legislative interest only in times like the present when investors' losses have been catastrophic.

${ }^{25}$ For example, the Federal Securities Act gives to the investor much greater protection against corporate managers and their associated bankers in connection with his original purchase of stock than has heretofore been vouchsafed him. The Securities Exchange Act will tend to curb speculation by managers and dominant stockholders at the expense of the small investor and will give the latter much more information than is now available to him with respect to the financial condition of those corporations whose securities are dealt in on a stock exchange. 
minds and feelings of the more influential portion of the group affected thereby. It follows that the legal standard applicable to the directors and other persons by whom our large business corporations are managed will prove extremely difficult of enforcement unless that standard is calculated to appeal to the managers themselves and thus to attain the status of a professional code of ethics rather than of a legal rule imposed upon an antagonistic group by the community at large.

One would have to be a far more hostile critic of the managers of big business than is the present writer to deny that the better element among them are motivated by a strong desire to conform-not merely because it is legal and safe but because they believe it to be ethically sound-to the legal principle of loyalty to stockholders which lies at the basis of corporate capitalism. Yet there would seem to be reason to believe that this attitude of mind is in considerable measure an anachronistic survival from an earlier period of different conditions when directors and stockholders were not strangers to one another. It is true that one who reads of the more scandalous incidents which arose out of the management of such large corporations as existed in the middle and later years of the nineteenth century ${ }^{16}$ may feel justified in insisting that there has been on the whole a change for the better. It would seem also that this change has not been wholly due to improvement in our machinery for law enforcement but in part at least to an improvement in the ethical standards of the typical corporation manager, which have made certain methods employed by the Fiskes and Goulds no longer good form. It may be that the comparative maturity of large-scale corporate capitalism tends towards control of it by persons of a less predatory type than those who frequently dominated at an earlier stage. A general improvement in business ethics has no doubt done much to overcome the tendency towards a weakening of loyalty that is brought about by the increasing separation between ownership and control.. ${ }^{77}$

\footnotetext{
${ }^{16}$ See Adams, supra note 2; Ripley, Railroads, Finance and Organization (IgI5). Certainly the misconduct by managers of large corporations is normally of a more subtle character than the bandit methods of the notorious Jim Fiske which are to-day characteristic of racketeering groups rather than of the managers of a great railroad or industrial corporation.

${ }^{27}$ There has been surprisingly little discussion by economists of the motives by which the managers of large corporations are governed. Adam Smith, writing at a time when the few corporations or joint-stock companies which existed were chiefly large enterprises engaged in foreign trade in which control and ownership were largely separate, assumed that these enterprises would of necessity be negligently and wastefully managed. See II Smith, The Wealth of Nations (Everyman's ed. r93I), 229. Marshall, writing in the light of recent English experience, has expressed a pleased surprise that modern English corporations are in general honestly managed despite the temptations involved in the divorce of control from ownership,
} 
Nevertheless, a critical examination of the nature of the legal principle involved-loyalty to stockholders - tends strongly to dispel any high degree of optimism with regard to the future. Under modern conditions loyalty to stockholders means an aggressive acquisitiveness not on one's own behalf, not on behalf of one's relatives, friends, or neighbors, or on behalf of persons with whom one is associated in the active carrying on of a common enterprise, but of a group of persons whose very names are unknown to their fiduciaries,- - a group of persons whose sole connection with the enterprise is in most cases the fact that they have purchased on the market shares which many of them hold not as permanent investment for their savings but in the hope of obtaining a trader's profit through resale to others..$^{88}$

The natural consequences of the absence of any personal relationship between the average stockholder and the management has been to some extent counteracted by the fact that even in corporations with widely dispersed stock ownership there are normally certain stockholders with whom the managers do have personal ties. This fact results in substantial protection to the rank and file of stockholders, however, only to the extent to which the latters' interests are identical with the interests of those who are close to the management. Where, as is frequently the case to-day, the stockholders associated with the management are all holders of a single class of stock whose interests are to some extent in conflict with those of other classes, or are stockholders of a holding company whose interests are in many respects opposed to those of individual stockholders in the subsidiaries, this kind of protection is, for important groups of stockholders, largely illusory. With respect to these groups, at least, what the law demands of corporate managers is vicarious acquisitiveness exercised on behalf of a group of persons with whom they have no contacts and no real identity of interest.

and has attributed the result to a general improvement in business ethics. Marshall, Principles of Economics (8th ed. r925), 305. Berle and Means have suggested that more could be learned of the motives which influence managers of large corporations "by studying the motives of an Alexander the Great, seeking new worlds to conquer, than by considering the motives of a petty tradesman of the days of Adam Smith." Berle and Means, The Modern Corporation and Private Property (I932), 350. Dewing believes that even the individual entrepreneur is motivated largely by ambitions which are not strictly economic. Dewing, The Financial Policy of Corporations (rev. ed. I926), 634 .

${ }^{18}$ Efficient managers may reasonably feel that the share of the profits customarily given to managers does not adequately measure the extent to which they, rather than the absentee owners of the capital, are responsible for the existence of profits. This may encourage them to adopt surreptitious means of diverting a substantial share of the profits into their own pockets. Larger legal rewards to managers might lessen the temptation to seek illegal rewards, but it is obvious that the temptation would still exist. 
It is true, no doubt, that men work not merely for wealth but for power and prestige, and it may be suggested that they may be willing to work faithfully for the financial profit of others, provided that substantial rewards in power and prestige accrue to them thereby. It may be questioned whether this view takes sufficient account of the fact that where men are directing an enterprise whose purpose is pecuniary profit, their natural tendency is to measure their own success primarily by their increase in wealth-a tendency which is particularlystrong, where, as is frequently the case, the direction of the enterprise is in the hands of those whose principal activities relate to finance rather than to productive operation. Assuming, however, that men would be willing to work loyally for the financial profit of strangers provided they thus acquired adequate prestige and power, it becomes necessary to consider how far prestige and power result to corporate managers as a result of loyalty rather than of undetected disloyalty.

Where the stockholders in a corporation are all of one class, disloyalty, even though undetected, involves a reduction of corporate profits and hence reduces the prestige which in a capitalistic society results from financially successful management. It tends also by reducing the financial strength of the corporation to check its growth and thereby reduce the opportunity for the management to acquire the power and prestige which results from presiding over the destinies of enterprises of great and growing size. This is counter-balanced to some extent by the opportunity which the managers may have to obtain power and prestige through the use in other enterprises of gains which they have made at the expense of the stockholders. Moreover, conduct which results in expansion of the enterprise may involve disloyalty to stockholders. It is far from being true that all forms of corporate expansion tend to increase the profits of stockholders, ${ }^{\text {I9 }}$ and the likelihood that they may not is greatly increased when stockholders are divided into classes with divergent interests. ${ }^{20}$

\footnotetext{
29 The managers' desire for expansion tends, to some extent, to keep them loyal to the investors' interests in order that they may induce the latter to invest additional funds in furtherance of an expansion program. Expansion is, however, in many cases financed out of accumulated profits. In order to accomplish this result the managers must, indeed, permit profits to accumulate, but these accumulated profits may be dissipated by an expansion which increases the managers' economic power but does not produce adequate returns for the investors. See Dewing, The Financial Policy of Corporations (rev. ed. r926), bk. IV, c. I.

${ }^{20}$ The possibilities of expansion of a type detrimental to certain groups of stockholders are further increased by the use of mergers and holding companies as methods of expansion. Merger requires the consent of the majority stockholders but despite this safeguard it can sometimes be arranged by an astute management on terms which are unfair to many of the stockholders of one or both of the merged corporations. Holding companies may, and not infrequently do, grow largely through the process of milking their subsidiaries. An excellent
} 
The ideal which corporate capitalism sets before corporation managers as one which should motivate their conduct is thus an ideal of profit-making on behalf of a group with whom they have in general no ties of personal association and a very incomplete identity of interest. Such an ideal seems one so little calculated to make a strong emotional appeal to the managers as to give those who are engaged in the endeavor to write that ideal into law much reason to fear that the law which they write will have to depend for its effectiveness primarily upon external compulsion rather than upon the internal harmony between the legal rules and the natural impulses of the group which is expected to govern its conduct thereby.

It may be urged that the difficulty which we are discussing, of producing a strong emotional response to the law of fiduciary obligations, is not confined to corporate capitalism but is inherent in all large-scale enterprise, whether its form be capitalist, socialist, or something else. The successful conduct of large-scale enterprise necessarily involves loyalty on the part of its managers to the interests of some group of human beings with whom they have no ties of blood or personal acquaintance and an incomplete identity of pecuniary interest. There is, however, this important difference between corporate capitalism and other types of large-scale enterprise, that the former presents to those who control it the peculiar ideal of vicarious acquisitiveness, whereas such other types of industrial organization as state socialism and consumer co-operatives offer to their managers an ideal in which motives other than acquisitiveness, personal or vicarious, predominate. One may readily agree with the defenders of capitalism that in our present state of society the desire for material acquisitions is stronger than the desire for service. One may agree that what is true of the present state of society is likely to be true of any state of society which attains to any high degree of material productivity. What most of the defenders of capitalism have ignored is, however, the fact that modern corporate capitalism is under the necessity of inculcating in its managers not primarily the desire for personal acquisitions but the desire for service to persons who are unknown to the managers and expect to be served merely because they have purchased shares in the enterprise with a view to profiting therefrom. Even if there were no historical examples by which to test one's theories, one might reasonably assume that if we must inculcate in the managers of an enterprise the ideal of service to some class of unknown persons, our chance of doing so successfully would be

résumé of suits against holding companies brought by minority stockholders of subsidiaries is contained in an appendix by Maurice Mound to Bonbright and Means, The Holding Company (1932), 343 . 
increased if the class of persons to be served bore some other relation to the enterprise than that of mere profit-seekers. Service to one's fellow workers, to those who have need of one's products, or to the social and political community of which one is a member would seem a less abnormal aim than vicarious profit-seeking.

Moreover, there is considerable historical warrant for the belief in the practicability of creating a relatively strong emotional appeal for at least one of the types of service referred to-service to that organized community which we call the State. Such service has in most civilized communities, from the age of Pericles to the age of Mussolini and Stalin, conferred upon the higher ranks of public servants power and prestige unequalled by that given to any other class in the community. If it has not done so in the United States, that is primarily because we have in the past tended to minimize the importance of government either by confining it to police functions in accordance with the theories of Herbert Spenser, or by making it the mere handmaiden of private enterprise, according to the principles and practices of Alexander Hamilton-a state of affairs now rapidly passing away. If, as has not infrequently been the case in the history of western civilization, men have been educated to regard the power and prestige of public office as more important than material riches, the attainment of a relatively high standard of pecuniary honor on the part of public servants may be--as the integrity of such groups as the English civil servants indicates ${ }^{2 x}$ - a matter of no great difficulty. That, granted the proper type of education, a community may develop in its public servants a very high degree of financial integrity is so clear that in the best governed communities it is not pecuniary dishonesty but such subtler types of disloyalty as playing safe where the needs of the community require boldness, giving the public what it or some particularly vocal portion of it seems at the moment to want rather than what it needs, and being something less than candid about one's blunders which are matters of serious concern. The problem of reducing to a minimum financial dishonesty on the part of the managers of a socialistic régime

\footnotetext{
${ }^{2 x}$ In well organized governments which have highly complex functions to perform, the best results are probably reached by dividing government, as in England, into a permanent nonpolitical civil service and elected political chiefs. The former may be given large managerial powers but major questions of policy must be decided by the latter if government is to be kept responsive to public opinion. It is the politician's preference for being popular rather than being right which is largely responsible for scepticism as to the superior loyalty of governmental over corporate officers. However, a competent, well-informed civil service can do much to check the vagaries of politicians, while the latter prevent the former from becoming an uncontrolled autocracy. For a valuable study of the English Civil Service, see British Civil Service, IX Fortune, no. 3, p. 98 (Mar. I934).
} 
should not, therefore, in a civilized community, prove to be one of insuperable difficulty, although other types of improper conduct on their part might well be harder to eradicate.

Consumer co-operatives have a much shorter and less thoroughly documented history than governments; but here, too, such evidence as exists seems to indicate that even when such enterprises are relatively large, dishonesty on the part of their managers has not been common..$^{22}$ The ideal of such enterprises, service to that portion of the community to whose needs the particular enterprise is designed to minister, seems to be one which is calculated to appeal to men and might appeal to them more strongly than it has in the past if the economic system were such as to make enterprises of this type important factors in the life of the community.

Business enterprises managed primarily in the interests of those who are workers therein have, largely owing to the inability of the workers to supply adequate capital, played such a minor rôle in human affairs that there are no adequate data for determining whether, if carried on as largescale enterprises, they would be likely to be honestly managed; ${ }^{23}$ but the history of the other two types of enterprises, governmental activities and consumer co-operatives, sufficiently indicates that those who manage enterprises for the benefit of persons with whom they have no ties of intimacy may under proper conditions learn to seek their rewards primarily in the form of power and prestige rather than of financial gain and may develop a satisfactory code of financial integrity. ${ }^{24}$

If, however, we turn from such enterprises to modern large-scale cor-

22 Probably the most important American corporations which are managed in the interest of those who are in effect consumers are the mutual savings banks and the mutual insurance companies. The management of these mutual companies, in those states with which the writer is familiar, has been notably free from scandals. For English co-operatives see Webb, The Consumers' Co-operative Movement (rg2I); for Continental co-operatives see Gide, Consumers' Co-operative Societies (English translation I922).

${ }^{23}$ The history of the business ventures of the Brotherhood of Locomotive Engineers may indicate that when officers of our existing labor unions become managers of capitalistic enterprises their standards of loyalty are not high. This does not prove that it would be difficult to build up a tradition of loyalty in the management of enterprises which were conducted for the benefit of the workers therein. Who can say what might be accomplished by the establishment of competent professional schools for the training of labor leaders?

24 If one assumes that the maximum possible increase in the material wealth of the community is socially desirable, the management of large business enterprises requires in addition to loyalty such qualities as intelligence, foresight, willingness to take risks and ability to avoid entanglement in coils of red tape. There is reason to believe that some of these qualities, particularly the last two, are more likely to be attained through corporate capitalism than through any other method of large-scale production. 
porate capitalism with its peculiar ideal of vicarious acquisitiveness, there would seem to be much greater reason for scepticism as to the practicability of arousing in its managers a voluntary spirit of loyalty to those for whom such enterprises are managed. Money-making being the whole aim and object of such enterprises, its managers are almost inevitably driven to measure their own success primarily by the amount of money which they can make out of management. Moreover, even where they are motivated more by desire for power and prestige than by desire for gain, they may often, as we have seen, find these aims most readily attainable by seeking either their own individual gain or that of some class of their beneficiaries with whose interests their own are largely identified, at the expense of some other group having divergent interests. In our modern complex corporate structure with its holding companies and its diverse classes of stock, the ideal of managerial loyalty to the investors' interests is thus one which is very difficult of attainment either by voluntary adoption of a code of ethics or by external legal compulsion.

Why then, it may be asked, should we seek to attain it? The proposition that the sole function of business organizations is to produce the maximum profit for absentee owners is not only one which cannot, in the nature of things, appeal strongly as a code of professional ethics to the managers; it is also one which no longer appeals strongly to the community as a social policy. It may well be that, as Berle and Means have suggested in the concluding chapter of The Modern Corporation and Private Property, ${ }^{25}$ we may be about to evolve "some wholly new concept of corporate activity"26 in which the rights of both absentee owners and of managers will be modified in the interest of employees, consumers and the community at large. As one of the authors of that book has pointed out, however, no legal principles exist by which the managers of private enterprise can be made to serve the interests of persons other than the investors. ${ }^{27}$ Certain minimum claims on the part of employees and consumers can be and to an increasing extent are being given legal formulation, but they do not substantially alter the basic principle. A duty to pay a legal minimum wage or to charge no more than a legal maximum price is not a duty of loyalty to employee or consumer. It is, as a general rule, a duty owed by the enterprise as a whole rather than by the managers personally. It is merely a modification of the rules of the game for the benefit of certain classes - a modification which does not affect the principle that the man-

25 Berle and Means, The Modern Corporation and Private Property (I932), bk. IV, c. IV.

${ }^{26} \mathrm{Ibid}$., p. 356 .

${ }_{27}$ Berle, For Whom Corporate Managers Are Trustees, 45 Harv. L. Rev. I365 (1932). 
agement is to play the game as representatives of another class-the investors. However much some modern corporate executives may like to think of themselves as trustees of an institution rather than attorneys for the stockholders, ${ }^{28}$ the law furnishes them with no guiding principles in accordance with which such trusteeship can be conducted.

Hence, as Mr. Berle tells us, the courts and the legal profession cannot relinquish the idea of treating managers as trustees for security holders without freeing the managers from substantial control of any kind.9 Profit-making for absentee owners must be the legal standard by which we measure their conduct until some other legal standard has been evolved. Granted-with some reservations ${ }^{30}$ that this is all that the law

${ }^{28}$ See Address of Owen D. Young, January, I929, quoted in Sears, The New Place of the Stockholder (r929), 209.

It is sometimes asserted that loyalty to the corporation as an economic institution is a psychologically satisfying idea which is well calculated to keep management both honest and efficient. Management of such an institution, however, involves the adjustment of the conflicting claims of the consumers, the workers, the stockholders and of the management itself. Legal tradition requires the managers to prefer the claims of the stockholders (except in so far as by fair and open bargaining with the latter they may establish their own claims). No doubt their present factual independence of the stockholders increases their de facto power to recognize other claims; but, apart from very recent experiments with N.I.R.A. codes, there are no standards of fair wages or fair prices other than those established by the bargaining of the market-place. Moreover, the tendency to give a dominating voice in management to financiers rather than to operating executives is a powerful deterrent to any managerial tendency to view the corporation as an instrument for the production and distribution of goods rather than as a device for profit-making. To the financier the important products of the corporation are money and salable securities-not commodities.

29 Berle, For Whom Corporate Managers Are Trustees, sitpra note 27, I371. Mr. Berle would not only have the courts preserve the "trusteeship for shareholders" point of view but he would have them extend this point of view to cover many situations which have been traditionally dealt with as matters of contract. See Berle, Corporate Powers as Powers in Trust, 44 Harv. L. Rev. 1049 (I93I). He argues effectively that to hold, as the Supreme Court did in Wabash Ry. Co. v. Barclay, 280 U.S. $x 97$ (1930), that holders of non-cumulative preferred stock have by contract surrendered all claim to earnings which are reinvested instead of paid out in dividends is to confer a dangerous power on the management. Nevertheless, the writer is very dubious of the gain to be derived from the attempt by equity judges to remake contracts permitted by the corporation statutes. He feels that the time has come for a thorough revision of our corporation statutes, such revision to be treated as an integral part of a general program for further governmental regulation of business in the interest not merely of the investor but of all classes involved. As indicated in the present article, the problem of providing adequate safeguards for the investor against managerial disloyalty is a very difficult one. It is believed, however, that much more can be done to remedy the existing situation by statutory enactment and by administrative regulation pursuant thereto than by a non-statutory extension of equity powers.

${ }^{30}$ Cf. Dodd, For Whom Are Corporate Managers Trustees? 45 Harv. L. Rev. Ir45 (r932). The writer believes that the time has arrived when courts may properly, in deciding such questions as the right of directors to deal liberally with the corporation's employees or to give corporate funds to local charities, stress to some extent the social obligations of the corporation 
can do at present, the question remains as to how effectively it can do that. If trusteeship for absentee investors, in addition to being an ideal having little emotional appeal to managers, is an ideal that is losing ground in the community generally and if the signs are multiplying that our economic order is evolving away from it, the prospect of its effective enforcement as an interim legal rule of conduct is not encouraging. Abandon it, as yet, we dare not-enforce it with more than moderate success, it is to be feared we cannot.

rather than confine their opinions to pointing out that such acts are often profitable in the long run. Perhaps the chief importance of the frank adoption of this point of view, in common law cases, is that it will make it easier for the courts to uphold the constitutionality of statutes in which a similar point of view is indicated. Thus, for example, the codes which have been adopted under authority of the National Industrial Recovery Act, involve concessions to labor with respect to wages and hours. These concessions have been formulated by the industries concerned, in other words, by corporate managers. It is arguable that they are valid exercises of managerial discretion to seek increased profits through increased purchasing power and also that they are valid as attempts by prudent management to forestall less voluntary and more drastic governmental regulation. It would seem, however, that they are in large measure a recognition by business, acting under governmental pressure, of its social responsibility to aid in lessening unemployment and increasing purchasing power and that judges will deal with them more intelligently if they recognize this fact. 